\title{
Article
}

\section{Different carbon sources optimizes soil temperature and im- proves soil water content in field grown spring wheat.}

\author{
Stephen Yeboah ${ }^{1,2,3,}$ Wu Jun ${ }^{1,2}$, Cai Liqun ${ }^{1,2}$, Patricia Oteng-Darko ${ }^{3}$ and Zhang Renzhi ${ }^{1,2^{*}}$ \\ ${ }^{1}$ College of Resources and Environmental Sciences, Gansu Agricultural University, Lanzhou, P.R. China \\ ${ }^{2}$ Gansu Provincial Key Lab of Aridland Crop Science, Gansu Agricultural University, Lanzhou, P.R. China \\ ${ }^{3}$ CSIR-Crops Research Institute, P.O. Box 3785 Kumasi, Ghana \\ *Correspondence: zhangrz@gsau.edu.cn or wujun210@126.com
}

\begin{abstract}
Water and nutrients shortage threatens agricultural sustainability in many arid and semiarid areas of the world. It is unknown whether improved water and nutrient conservation practices can be developed to alleviate this issue while increasing crop productivity. In this study, experimental work included the application of straw, biochar and $\mathrm{N}$ fertilizer. The straw and biochar were applied alone or combined with $\mathrm{N}$ fertilizer $\left(0\right.$ and $\left.100 \mathrm{~kg} \mathrm{~N} \mathrm{ha}^{-1}\right)$. Application of biochar and straw in combination with $\mathrm{N}$ fertilizer caused a reduction in mean soil temperature by an average of $20.05 \%$ and $18.10 \%$ relative to soils without carbon. Biochar and straw- amended soils significantly $(\mathrm{P}<0.05)$ increased soil moisture content by $11.04 \%$ and $13.68 \%$ compared to no carbon treatments. Statistically comparable temperatures and moisture were recorded for both straw and biochar treated plots. Both biochar and straw treated soils produced the lowest bulk density $(0-5 \mathrm{~cm})$ at 1.15 $\mathrm{g} \mathrm{cm}^{-3}$, and no carbon soils the highest at $1.20 \mathrm{~g} \mathrm{~cm}^{-3}$. The improved soil quality translated into higher biomass in the biochar $\left(1906 \mathrm{~kg} \mathrm{ha}^{-1}\right)$ and biomass $\left(1643 \mathrm{~kg} \mathrm{ha}^{-1}\right)$ and soils without carbon the lowest at $1553 \mathrm{~kg} \mathrm{ha}^{-1}$. The improvement of soil moisture and the optimization of soil temperature for the two residue treated soils allow us to conclude that combined application of biochar and straw at the rate used in this study can be used as an effective farming model in alleviating water and nutrient shortage in semiarid environments.
\end{abstract}

Keywords: biochar; dryland; residue; nitrogen fertilizer; straw; wheat productivity

\section{Introduction}

Inadequate water and nutrient supplies limit crop yields in the western Loess Plateau of China. Rainfall availability and soil fertility depletion are the main factors influencing successful crop establishment and yield in the northwestern province of China [1, 2]. Cropping in the Loess Plateau is dependent on availability of rainfall, but this can be erratic and with high inter-annual variation [1]. Spring wheat is one of the dominant crops in this region, but its growth is restricted by the limited and erratic rainfall [3].Thus, yield of spring wheat in this region is far less than potential yield, ranging from 1500 to $3000 \mathrm{~kg}$ $\mathrm{ha}^{-1}[1]$. The region is primarily used for crop production, but it is also severely affected by soil erosion and high evaporative losses, which therefore restrict productivity [4]. These effects have reduced soil resilience and therefore can have long-term implications for food security to the rural communities [5]. Farmers needs to manage water and nutrient resources wisely to ensure long-term agricultural sustainability and local food security. Optimizing soil temperature and increasing soil water content is a major goal for achieving sustainable spring wheat production, which will have a great impact at local and regional scale. 
Responses to the harsh conditions include adequate fertilization programs and effective soil and water conservation techniques for semiarid environments. Some of these practices are being implemented in the NW of China [6] with satisfactory results in terms of improved rainfall-use efficiency. The adoption of sound soil management strategies such as, crop residues practices, biochar application and efficient $\mathrm{N}$ fertilization has been suggested to improve soil water and nutrients $[9,10]$. These strategies can be achieved by increased input of crop residues while minimizing $C$ loses by erosion, decomposition and carbon emission. The incorporation of biochar into soil varies soil structure, porosity and bulk density [10]. According to [10] this may in turn have consequences for important soil functions such as soil water and nutrient retention and plant growth. Nitrogen fertilization impact on soil temperature and moisture by enhancing crop biomass production and stabilize microclimate in soil and thus impact soil productivity [11]. Soil application of organic materials couple with appropriate $\mathrm{N}$ fertilization could significantly improve soil microenvironments, thus increasing crop yields and resource use efficiency.

Based on many years of experimentation on the regulation mechanisms for soil temperature and moisture, we propose application of biochar and straw alone or integrated together with nitrogen fertilization in the spring wheat cropping system. This study hypothesized that increased $C$ inputs alone or in combination with nitrogen fertilizer would raise the soils potential to optimize soil temperature, increase soil moisture content whiles increasing straw yield. In testing the hypothesis, we determined (ii) the change of soil temperature and soil moisture during key plant growth stages under the continuous spring wheat systems.

\section{Materials and Methods}

\subsection{Experimental site}

The study was conducted at the Dingxi Experimental Station $\left(35^{\circ} 28^{\prime} \mathrm{N}, 104^{\circ} 44^{\prime} \mathrm{E}\right.$, elevation 1971-m above-sea-level) of the Gansu Agricultural University in Northwestern China. The research station is located in the semiarid Western Loess Plateau, which is characterized by step hills and deeply eroded gullies. This area has Aeolian soils of sandyloam with low fertility, locally known as Huangmian soils [12]. This soil type has a sandyloam texture and relatively low fertility with $\mathrm{pH}$ of $\approx 8.3$, soil bulk density of $1.19 \mathrm{~g} \mathrm{~cm}^{-3}$, soil organic carbon (SOC) of $8.13 \mathrm{~g} \mathrm{~kg}^{-1}$ from $0-30 \mathrm{~cm}$ soil depth, and Olsen-P $\leq 13 \mathrm{mg} \mathrm{kg}^{-1}$. Long-term (annual) rainfall records for Dingxi station show an average of $390.9 \mathrm{~mm}$ per year; annual evaporation was $1531 \mathrm{~mm}$; aridity was 2.53. Annual cumulative temperatures $>10^{\circ} \mathrm{C}$ are $2239.1^{\circ} \mathrm{C}$ and annual radiation was $5929 \mathrm{MJ} \mathrm{m}^{-2}$, with $2476.6 \mathrm{~h}$ of sunshine. The climate is warm, sunny and moist during summer. In-crop season rainfall recorded at the site during the course of the experiment was 174.6, 252.5 and $239.4 \mathrm{~mm}$ in 2014, 2015 and 2016 respectively. Daily rainfall recorded during the course of the study is presented in Figure 1. 

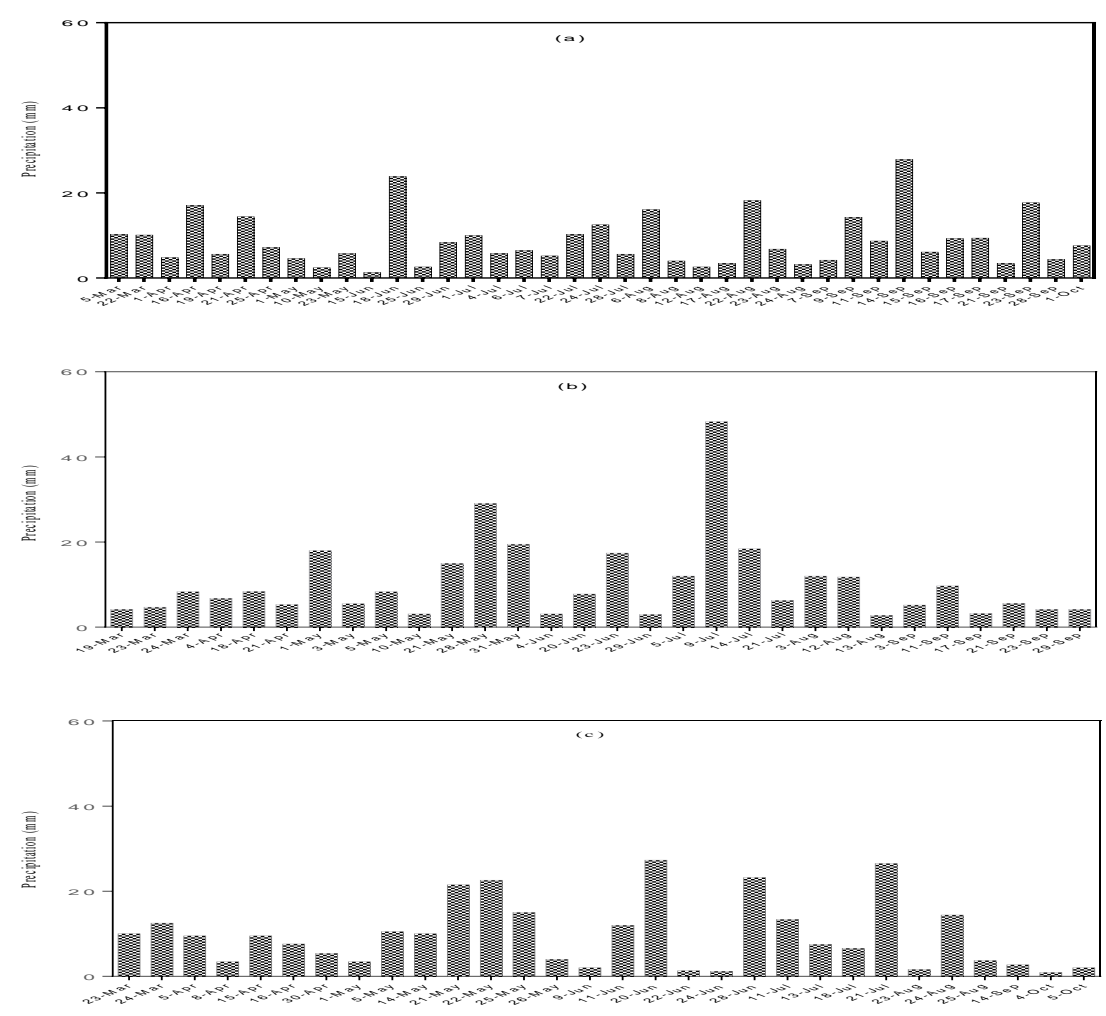

Figure 1: Daily rainfall records for the 2014 (a), 2015 (b) and 2016 (c) season

\subsection{Experimental design and treatment description}

The experiment involved addition of different carbon (C) sources; namely: biochar and straw, and $\mathrm{N}$ fertilizer in the form of urea $(46 \% \mathrm{~N})$ arranged in a randomized block design with 6 treatments and 3 replications. The treatments were: $\mathrm{CN}_{0}-$ control (zeroamendment), $\mathrm{CN}_{100}-100 \mathrm{~kg} \mathrm{ha}^{-1} \mathrm{~N}$ applied each year, $\mathrm{BN}_{0}-15 \mathrm{tha}-1$ biochar applied in a single dressing in 2014, $\mathrm{BN}_{100}-15 \mathrm{t} \mathrm{ha}^{-1}$ biochar (single dressing in 2014) $+100 \mathrm{~kg} \mathrm{ha}^{-1}$ $\mathrm{N}$ applied each year, $\mathrm{SN} 0-4.5 \mathrm{tha}^{-1}$ straw applied in 2014 and SN100 $-4.5 \mathrm{t} \mathrm{ha}^{-1}$ straw in $2014+100 \mathrm{~kg} \mathrm{ha}^{-1} \mathrm{~N}$ applied each year. Biochar and straw were applied at the same quantity based on the straw returned to the soil. Biochar was incorporated into the soil using a rotary tillage implement to a depth of $\approx 10 \mathrm{~cm}$. The biochar used in the experiment is a commercial milled charcoal sourced from a local supplier (Golden Future Agriculture Technology Co., Ltd, Liaoning, China). In straw-amended plots, the wheat straw from the previous crop was weighted and returned to the original plots immediately after threshing and spread evenly on the soil surface. The biochar and straw properties were, respectively, 0.43 and $0.38 \mathrm{~g} \mathrm{~g}^{-1}$ of total carbon, and 1.04 and $0.94 \mathrm{~g} \mathrm{~kg}^{-1}$ of total nitrogen. All the treatments received a blanket application of phosphorus $(\mathrm{P})$ fertilizer, which was applied at $46 \mathrm{~kg} \mathrm{ha}^{-1} \mathrm{P}$ as ammonium dihydrogen phosphate $\left(12 \% \mathrm{~N}, 52 \% \mathrm{P}_{2} \mathrm{O}_{5}\right)$ at sowing using a no-tillage seeder (depth: $\approx 20 \mathrm{~cm}$ ). Spring wheat (Triticum aestivum L. cv. Dingxi 35) was sown continuously around the middle of March at a rate of $188 \mathrm{~kg} \mathrm{ha}^{-1}$ seeds at $20-\mathrm{cm}$ row spacing, and it was harvested each year between late July and early August. The plot's dimensions were $3-\mathrm{m}$ by $6-\mathrm{m}$. 


\subsection{Determination of soil temperature}

Soil temperature (Ts) at 5, 10, $15 \mathrm{~cm}$ were determined using a thermo-couple (JM624, Tianjin Jinming Instrument Co. Ltd., China) from each plot.

\subsection{Determination of soil moisture}

Soil moisture at the $0-5,5-10$ and $10-30 \mathrm{~cm}$ depth intervals was determined by taking a soil core of $5-\mathrm{cm}$ in diameter, and subsequently drying the soil at $105^{\circ} \mathrm{C}$ for $24 \mathrm{~h}$. Gravimetric water content at the three depth intervals was multiplied by soil bulk density (Blake and Harge, 1986) to obtain the volumetric water content, which is expressed in $\mathrm{cm} 3$ $\mathrm{cm}^{-3}$. Soil samples for moisture were taken from inside the plots.

\subsection{Determination of soil bulk density}

Soil bulk density (BD) was determined by taking small cores, and by relating the oven-dried mass of soil to the volume of the core [13].

\subsection{Carbon-to-nitrogen ratio}

The carbon-to-nitrogen ratio $(\mathrm{C} / \mathrm{N})$ was calculated from the soil organic carbon (Table S1) and total nitrogen content (Table S2) determined.

\subsection{Biomass yield}

Plots were harvested by using hand sickles to a height of $5 \mathrm{~cm}$ aboveground and by discarding the outer edges $(0.5-\mathrm{m})$ from each plot. Biomass yield was determined on a dry-weight basis by oven-drying the plant material at $105^{\circ} \mathrm{C}$ for $45 \mathrm{~min}$ and then to constant weight at $85^{\circ} \mathrm{C}$.

\subsection{Statistical analyses}

Statistical analyses were undertaken with the Statistical Product Services Solution "22.0” (IBM Corporation, Chicago, IL, USA) with the treatment as the fixed effect and year as random effect. Differences between-treatments means were determined using Duncan's Multiple Range (Duncan, 1955). Significance was determined using a probability level of $5 \%$

\section{Results}

\subsection{Seasonal variations in soil temperature}

Temperature changes for the upper 0-15 cm soil depth from the different treatments are given in Figure 2. Seasonal temperature increased with time after sowing, and produced a major peak on 21 June, 3 July and 20 July in 2014, 2015 and 2016 respectively. It declined after harvest in August of each year. Generally, higher soil temperatures were recorded during the cropping year 2014 (ranges between 12.74 to $25.01^{\circ} \mathrm{C}$, Figure 2a), followed by 2016 (ranges 11.80 to $24.30{ }^{\circ} \mathrm{C}$, Figure 2c) and then 2015 (ranges 10.91 to $23.79^{\circ} \mathrm{C}$, Figure $2 \mathrm{~b}$ ). Biochar and straw amended soils consistently had the lowest soil temperature in many instances during the sampling period, whereas no carbon treatment had the highest temperature during the measurement period in all depths. Significant differences $(P<0.05)$ were observed among treatments in some instances of measurement (Figure 2). During the sampling period, differences between straw and biochar treated plots were mostly not significant at $\mathrm{P}<0.05$. This section may be divided by subheadings. It should provide a concise and precise description of the experimental results, their interpretation, as well as the experimental conclusions that can be drawn. 


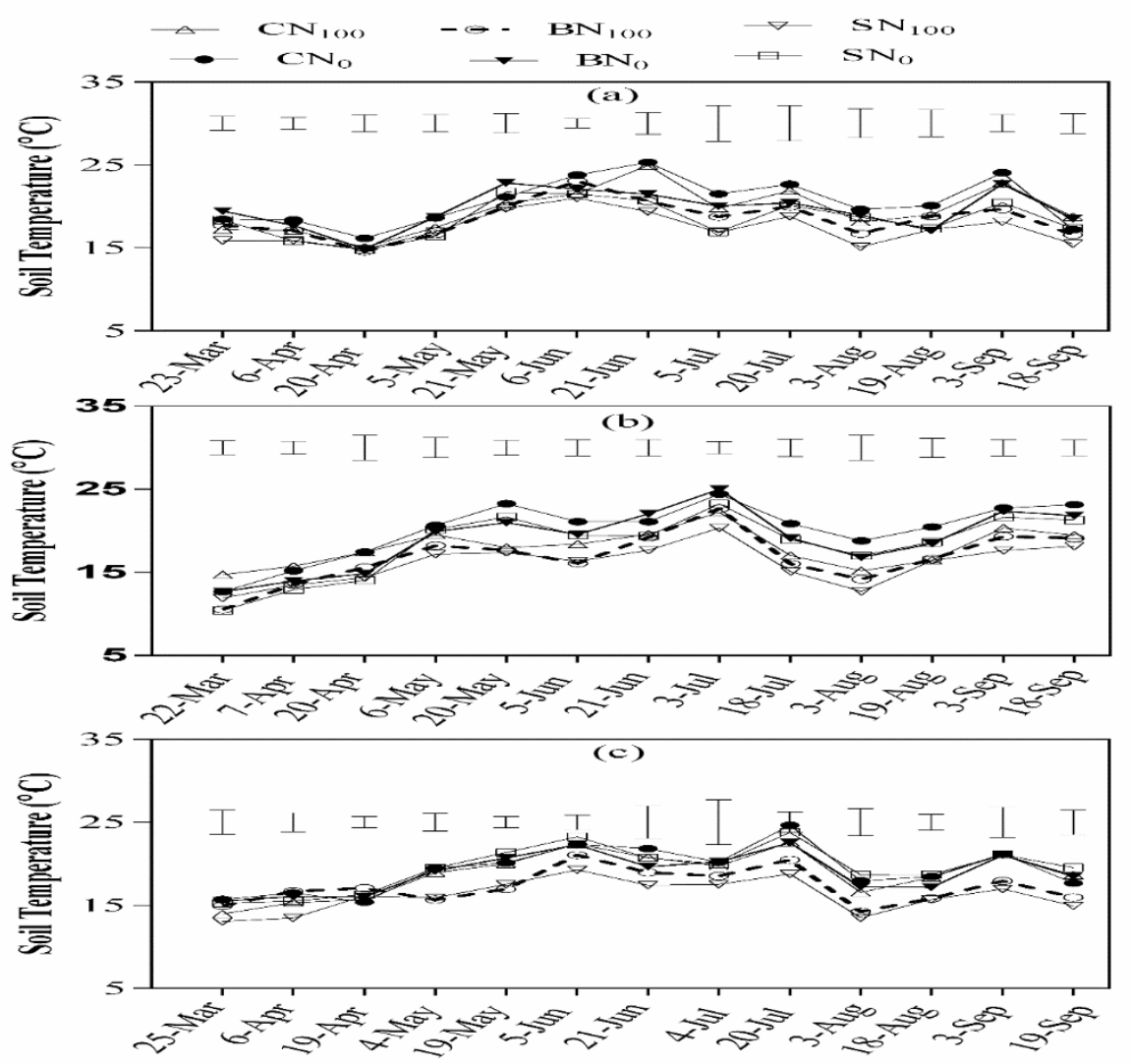

Figure 2: Mean soil temperature at 5, 10, and $15 \mathrm{~cm}$ soil depth in 2014 (a), 2015 (b) and 2016 (c) as affected by carbon addition sources. The vertical bars represent the least significant difference (LSD) at $\mathrm{P}<0.05$ among treatments within a measurement date

\subsection{Seasonal variations in soil moisture}

The seasonal soil moisture trends over the study period are presented in Figure 3. Generally, the highest seasonal soil moisture values were recorded in straw and biochar treated plots. Lower seasonal soil moisture content was recorded in no carbon treated soils in each of the study year. On the whole, the highest seasonal soil moisture occurred on July 20 in 2014, July 18 in 2015 and June 21 in 2016. The lowest seasonal soil moisture was recorded in March and April. Higher moisture contents were recorded during the cropping year $2015\left(13.82-19.10 \mathrm{~cm}^{3} \mathrm{~cm}^{-3}\right.$, Figure $\left.3 b\right)$, followed by $2016\left(10.99-16.88 \mathrm{~cm}^{3}\right.$ $\mathrm{cm}^{-3}$, Figure 3c) and then $2014\left(7.28-13.51 \mathrm{~cm}^{3} \mathrm{~cm}^{-3}\right.$, Figure 3a). In 2014 and 2015, the soil moisture content peaked twice whiles a single peak was observed in 2016. The soil moisture differs significantly $(\mathrm{P}<0.05)$ on certain occasions of measurements. During this period of measurement, straw and biochar treated soils mostly had higher soil moisture content whiles the lowest soil moisture content were recorded from the soils without carbon. Moreover, on many occasions the seasonal soil moisture did not differ $(\mathrm{P}<0.05)$ between straw and biochar treated plots. 


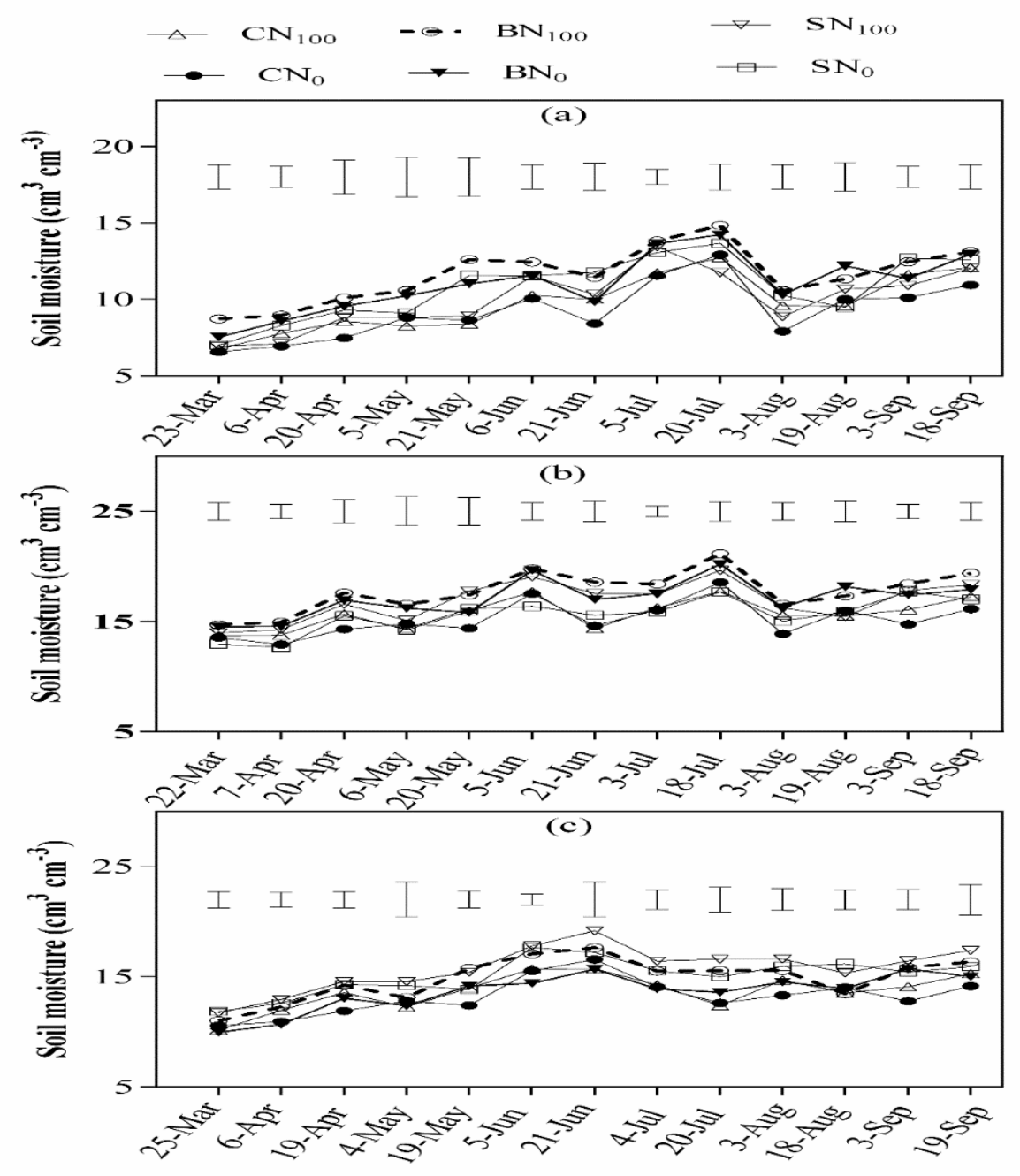

Figure 3: Mean soil moisture content $(\mathrm{cm} \mathrm{cm}-3)$ at $0-5,5-10$, and $10-30 \mathrm{~cm}$ soil depth in 2014 (a), 2015 (b) and 2016 (c) as affected by carbon addition sources. The vertical bars represent the least significant difference (LSD) at $\mathrm{P}<0.05$ among treatments within a measurement date.

\subsection{Variations in mean soil temperature and moisture}

Carbon, nitrogen and year had significant effect $(\mathrm{P}<0.05)$ on mean soil temperature (Table 1) and significant interaction between carbon and year in affecting soil temperature in $0-5$ and 5-10 $\mathrm{cm}$ was observed. Application of $\mathrm{SN}_{100}$ caused a reduction in mean soil temperature at the $0-5 \mathrm{~cm}$ soil depth compared to $\mathrm{CN}_{0}$; an average increase of $21.03 \%$ was recorded (Table 2). Statistically comparable temperatures were recorded for both straw and biochar treatments, whereas slightly increased temperatures (ranges from $6.65 \%$ to $8.12 \%$ ) were recorded in the no carbon treatments. The lowest soil temperature recorded under the highest $\mathrm{N}$ fertilizer rates $\left(\mathrm{N}_{100}\right)$ was significant at $\mathrm{P}<0.05$ compared to their zero amended soil in most instances. The mean soil temperature had a decreasing trend with increasing in soil layer; this was consistent for all the years of this study.

Carbon and year independently had significant $(\mathrm{P}<0.05)$ influence on soil moisture content in the layers reported here (Table 1), and their interactions were significant in affecting soil moisture content in all the layers studied. When compared to all treatments, the highest soil moisture contents were recorded in response to the biochar amended soils, followed by straw amended soils and the least soil moisture was noted in no carbon soils 
(Table 3). The highest soil moisture content was observed in 5-10 cm under all treatments. Biochar and straw- amended soils significantly $(\mathrm{P}<0.05)$ increased soil moisture content by $11.04 \%$ and $13.68 \%$ compared to no carbon treatments. Application of $\mathrm{N}_{0}$ treatment had lower soil moisture contents in all treatments and depths.

Table 1: Analysis of variance for carbon and nitrogen fertilizer effects and their interaction

\begin{tabular}{|c|c|c|c|c|c|c|}
\hline \multirow[t]{2}{*}{ Source } & \multicolumn{3}{|c|}{ Soil temperature (OC ) } & \multicolumn{3}{|c|}{ Soil moisture $(\mathrm{cm} 3 \mathrm{~cm}-3)$} \\
\hline & $0-5$ & $5-10$ & $10-30$ & $0-5$ & $5-10$ & $10-30$ \\
\hline Carbon (C) & $21.22^{* * *}$ & $9.37^{* * *}$ & $8.69^{* * *}$ & $17.27^{* * *}$ & $15.45^{* * *}$ & $22.71^{* * *}$ \\
\hline Nitrogen $(\mathrm{N})$ & $35.31^{* * *}$ & $23.13^{* * *}$ & $14.85^{* * *}$ & 0.62 n.s. & $14.47^{* * *}$ & $22.01^{* * *}$ \\
\hline Year $(Y)$ & $8.84^{* * *}$ & $77.68^{* * *}$ & $33.66^{* * *}$ & $43.93^{* * *}$ & $33.04^{* * *}$ & $15.40^{* * *}$ \\
\hline $\mathrm{C} \times \mathrm{N}$ & $3.01^{*}$ & $0.62 \mathrm{n} . \mathrm{s}$ & 0.68 n.s. & 1.44 n.s. & 0.77 n.s. & 0.83 n.s \\
\hline $\mathrm{CxY}$ & $2.60^{*}$ & $2.69^{*}$ & 0.31 n.s. & $6.89^{* * *}$ & $7.68^{* * *}$ & $4.90^{* *}$ \\
\hline $\mathrm{N} x \mathrm{Y}$ & 0.57 n.s. & 1.02 n.s. & 0.54 n.s. & $5.66^{* *}$ & $2.50^{*}$ & 1.29 n.s. \\
\hline Error & 1.12 & 1.10 & 1.44 & 0.89 & 1.27 & 1.31 \\
\hline
\end{tabular}

$*, * * * * *$ indicate significant difference at $\mathrm{P}<0.05, \mathrm{P}<0.01, \mathrm{P}<0.001$ respectively. n.s. indicate no significance difference at $\mathrm{P}<0.05$

Table 2: Soil temperature as affected by carbon addition sources

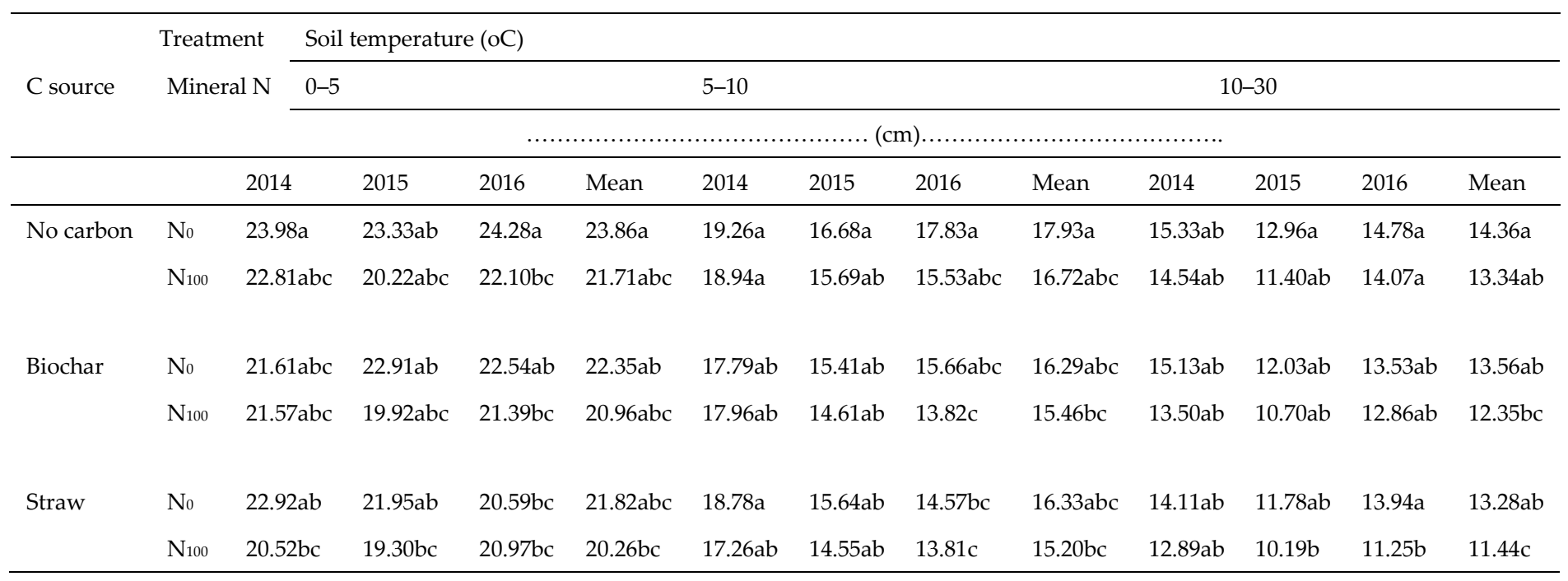

Values with different letters within a column are significantly different at $\mathrm{P}<0.05$ 
Table 3: Soil moisture content as affected by carbon addition sources

Treatment Soil moisture $(\mathrm{cm} 3 \mathrm{~cm}-3)$

\begin{tabular}{|c|c|c|c|c|c|c|c|c|c|c|c|c|c|}
\hline \multirow[t]{2}{*}{ C source } & \multicolumn{2}{|c|}{ Mineral N } & \multicolumn{4}{|l|}{-5} & \multicolumn{3}{|l|}{ 5-10 } & \multicolumn{3}{|l|}{$10-30$} & \multirow[b]{2}{*}{ Mean } \\
\hline & & 2014 & 2015 & 2016 & Mean & 2014 & 2015 & 2016 & Mean & 2014 & 2015 & 2016 & \\
\hline \multirow[t]{2}{*}{ No carbon } & $\mathrm{N}_{0}$ & $6.47 \mathrm{~b}$ & $8.97 \mathrm{~b}$ & $8.91 \mathrm{c}$ & $8.11 b$ & $13.91 b$ & $14.11 \mathrm{c}$ & $14.62 \mathrm{c}$ & $14.21 \mathrm{c}$ & $12.37 \mathrm{~b}$ & $13.21 \mathrm{~b}$ & $10.76 \mathrm{~b}$ & $12.11 \mathrm{c}$ \\
\hline & $\mathrm{N}_{100}$ & $7.29 \mathrm{ab}$ & 11.41ab & 11.07ab & $9.93 \mathrm{ab}$ & $13.89 b$ & $15.53 b c$ & 17.19ab & 15.54abc & $13.03 \mathrm{ab}$ & $13.23 b$ & 13.33ab & $13.19 b c$ \\
\hline \multirow[t]{2}{*}{ Biochar } & $\mathrm{N}_{0}$ & $8.18 \mathrm{ab}$ & $9.08 b$ & $8.92 \mathrm{c}$ & $8.72 \mathrm{ab}$ & $14.59 \mathrm{ab}$ & $15.59 b c$ & $15.22 \mathrm{c}$ & $15.13 \mathrm{bc}$ & $12.73 \mathrm{ab}$ & $13.52 b$ & $12.71 \mathrm{ab}$ & $12.99 \mathrm{bc}$ \\
\hline & $\mathrm{N}_{100}$ & $8.91 \mathrm{a}$ & $10.30 \mathrm{ab}$ & $11.64 a$ & $10.28 \mathrm{a}$ & $15.36 \mathrm{ab}$ & 17.85ab & $18.48 \mathrm{a}$ & $17.23 a$ & $14.29 \mathrm{ab}$ & $15.92 \mathrm{ab}$ & $15.52 \mathrm{a}$ & $15.24 \mathrm{a}$ \\
\hline Straw & $\mathrm{N}_{0}$ & $8.95 a$ & $8.81 b$ & $9.53 b c$ & $9.10 \mathrm{ab}$ & $13.76 \mathrm{~b}$ & $16.55 \mathrm{abc}$ & 17.23ab & $15.84 \mathrm{abc}$ & $14.34 \mathrm{ab}$ & $14.48 \mathrm{ab}$ & $13.68 \mathrm{ab}$ & $14.17 \mathrm{ab}$ \\
\hline
\end{tabular}

Values with different letters within a column are significantly different at $P<0.05$

\subsection{Soil bulk density}

Soil samples taken during the study period showed significant differences in the bulk density (BD) depending on the type of treatment and the depth of sampling (Table 4). Carbon, $\mathrm{N}$ fertilizer had significant effect on bulk density, although differences were not significant at $\mathrm{P}<0.05$ in some depths (Table 4). It was clear that the bulk density increased with soil depth in many cases irrespective of treatment over the experimental period. Significant differences between treatments were minor in the upper layer in 2014, but significant treatment effect was recorded in the $5-10 \mathrm{~cm}$ soil depth as the experimental period progressed from 2014 to 2016 (Table 5). The lowest averaged bulk density $\left(1.14 \mathrm{~g} \mathrm{~cm}^{-3}\right)$ was found with biochar-amended soils, the highest with no carbon soils $\left(1.21 \mathrm{~g} \mathrm{~cm}^{-3}\right)$ which represent a significant decrease of $6.14 \%$. The results obtained with the strawamended soil showed a similar trend, except that differences were not significant at $\mathrm{P}<$ 0.05 in most cases. Bulk densities of the straw-amended soil were not significantly different $(\mathrm{P}<0.05)$ compared to biochar-amended soils.

Table 4: Analysis of variance for factors and their interaction

\begin{tabular}{llllll}
\hline \multirow{2}{*}{ Source } & \multicolumn{4}{l}{ Soil bulk density } & \multicolumn{2}{l}{ C/N ratio } \\
\cline { 2 - 6 } & $0-5$ & $5-10$ & $0-5$ & $5-10$ & Stubble yield \\
\hline Carbon (C) & $11.10^{* * *}$ & $12.06^{* * *}$ & $9.30^{* * *}$ & $4.82^{*}$ & $83.80^{* * *}$ \\
Nitrogen (N) & $8.19^{* *}$ & 0.77 n.s. & 0.43 n.s. & 0.19 n.s. & $157.11^{* * *}$ \\
Year (Y) & 0.03 n.s. & $5.43^{* *}$ & $6.94^{* *}$ & $3.19^{*}$ & $55.02^{* * *}$ \\
C x N & 0.98 n.s. & 1.61 n.s. & 0.40 n.s. & 0.18 n.s. & $3.12^{*}$ \\
C x Y & 0.10 n.s. & 1.38 n.s. & 1.90 n.s. & 1.10 n.s. & 0.37 n.s. \\
N x Y & 0.70 n.s. & 0.33 n.s. & 0.49 n.s. & 0.45 n.s. & $2.53^{*}$ \\
Error & 0.003 & 0.005 & 1.302 & 1.785 & 28889.56 \\
\hline
\end{tabular}

$*, * *, * * *$ indicate significant difference at $\mathrm{P}<0.05, \mathrm{P}<0.01, \mathrm{P}<0.001$ respectively. n.s. indicate no significance difference at $\mathrm{P}<0.05$. 
Table 5: Soil bulk density as affected by carbon addition sources

\begin{tabular}{|c|c|c|c|c|c|c|}
\hline \multicolumn{2}{|c|}{ Treatment } & \multicolumn{5}{|c|}{ Soil BD $\left(\mathrm{g} \mathrm{cm}^{-3}\right)$} \\
\hline \multirow[t]{2}{*}{ C source } & \multirow[t]{2}{*}{ Mineral N } & $0-5$ & \multicolumn{4}{|l|}{$5-10$} \\
\hline & & Mean & 2014 & 2015 & 2016 & Mean \\
\hline \multirow[t]{2}{*}{ No carbon } & $\mathrm{N}_{0}$ & $1.24 \mathrm{a}$ & $1.32 \mathrm{a}$ & $1.30 \mathrm{ab}$ & $1.27 \mathrm{a}$ & $1.29 \mathrm{a}$ \\
\hline & $\mathrm{N}_{100}$ & $1.20 \mathrm{ab}$ & $1.20 \mathrm{a}$ & $1.17 \mathrm{~cd}$ & $1.12 \mathrm{c}$ & $1.16 \mathrm{bc}$ \\
\hline \multirow[t]{2}{*}{ Biochar } & $\mathrm{N}_{0}$ & $1.17 \mathrm{bc}$ & $1.25 \mathrm{a}$ & $1.25 \mathrm{abc}$ & $1.24 \mathrm{ab}$ & $1.25 \mathrm{abc}$ \\
\hline & $\mathrm{N}_{100}$ & $1.15 \mathrm{bcd}$ & $1.21 \mathrm{a}$ & $1.18 \mathrm{bcd}$ & $1.17 b c$ & $1.19 b c$ \\
\hline \multirow[t]{2}{*}{ Straw } & $\mathrm{N}_{0}$ & $1.21 \mathrm{ab}$ & $1.22 \mathrm{a}$ & $1.32 \mathrm{a}$ & $1.23 \mathrm{ab}$ & $1.25 \mathrm{ab}$ \\
\hline & $\mathrm{N}_{100}$ & $1.14 \mathrm{~cd}$ & $1.28 \mathrm{a}$ & $1.18 \mathrm{~cd}$ & $1.16 b c$ & $1.21 \mathrm{abc}$ \\
\hline
\end{tabular}

Values with different letters within a column are significantly different at $\mathrm{P}<0.05$

\subsection{Carbon-to-nitrogen ratio}

Table 4 shows the treatment effect and their interaction on carbon-to-nitrogen ratio $(\mathrm{C} / \mathrm{N})$ of the soil. Carbon and year had effect on $\mathrm{C} / \mathrm{N}$ ratio thought not significant at $\mathrm{P}<$ $0.05 \mathrm{in} 10-30 \mathrm{~cm}$. The interaction between the treatment factors recorded no significant effect on $\mathrm{C} / \mathrm{N}$ ratio in all layers studied here. Regardless of year, biochar treatment exhibited a higher $\mathrm{C} / \mathrm{N}$ ratio than straw and no carbon soils (Table 6). These differences were not significant in most of the layers. Application of BN50 significantly increased $\mathrm{C} / \mathrm{N}$ ratio at $0-5 \mathrm{~cm}$ by $12.48 \%, 13.47 \%$ and $12.53 \%$ compared to $\mathrm{CN}_{0}, \mathrm{CN}_{50}$ and $\mathrm{CN}_{100}$ respectively (Table 6). Similar results were observed in $5-10 \mathrm{~cm}$. The biochar treated soils showed higher $\mathrm{C} / \mathrm{N}$ ratio compared to straw treated soils, but the difference were not always significant. Significant differences $(\mathrm{P}<0.05)$ were not found between straw and no carbon treated soils in all layers studied.

Table 6: Carbon-to-nitrogen ratio of various carbon addition sources

\begin{tabular}{|c|c|c|c|c|c|c|c|c|c|}
\hline \multirow{4}{*}{ C source } & \multirow{4}{*}{$\begin{array}{l}\text { Treatment } \\
\text { Mineral N }\end{array}$} & \multicolumn{8}{|c|}{$\mathrm{C} / \mathrm{N}$ ratio } \\
\hline & & \multicolumn{4}{|l|}{$0-5$} & \multicolumn{4}{|l|}{$5-10$} \\
\hline & & \multicolumn{8}{|c|}{ 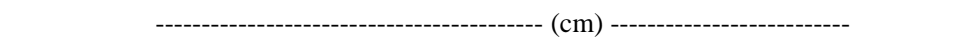 } \\
\hline & & 2014 & 2015 & 2016 & Mean & 2014 & 2015 & 2016 & Mean \\
\hline \multirow[t]{2}{*}{ No carbon } & $\mathrm{N}_{0}$ & $11.31 \mathrm{a}$ & $11.21 \mathrm{a}$ & $11.10 \mathrm{~b}$ & $11.21 \mathrm{bc}$ & $11.22 \mathrm{a}$ & $11.11 \mathrm{a}$ & $10.65 \mathrm{c}$ & $10.99 \mathrm{a}$ \\
\hline & $\mathrm{N}_{100}$ & $11.00 \mathrm{a}$ & $11.59 \mathrm{a}$ & $11.08 \mathrm{~b}$ & $11.22 \mathrm{bc}$ & $10.70 \mathrm{a}$ & $10.94 \mathrm{a}$ & $11.16 \mathrm{c}$ & $10.93 \mathrm{a}$ \\
\hline \multirow[t]{2}{*}{ Biochar } & $\mathrm{N}_{0}$ & $12.18 \mathrm{a}$ & $11.17 \mathrm{a}$ & $13.89 \mathrm{a}$ & $12.41 \mathrm{abc}$ & $12.02 \mathrm{a}$ & $10.37 \mathrm{a}$ & $12.72 \mathrm{ab}$ & $11.70 \mathrm{a}$ \\
\hline & $\mathrm{N}_{100}$ & $11.63 \mathrm{a}$ & $12.35 \mathrm{a}$ & $13.09 \mathrm{a}$ & $12.35 \mathrm{abc}$ & $10.89 \mathrm{a}$ & $12.28 \mathrm{a}$ & $12.95 \mathrm{ab}$ & $12.04 \mathrm{a}$ \\
\hline \multirow[t]{2}{*}{ Straw } & $\mathrm{N}_{0}$ & $11.46 \mathrm{a}$ & $11.14 \mathrm{a}$ & $11.53 b$ & $11.37 \mathrm{abc}$ & $11.12 \mathrm{a}$ & $10.35 \mathrm{a}$ & $11.75 \mathrm{bc}$ & $11.09 \mathrm{a}$ \\
\hline & $\mathrm{N}_{100}$ & $11.48 \mathrm{a}$ & $11.03 \mathrm{a}$ & $13.32 \mathrm{a}$ & $10.97 \mathrm{abc}$ & $11.47 \mathrm{a}$ & $10.77 \mathrm{a}$ & $11.41 \mathrm{abc}$ & $11.42 \mathrm{a}$ \\
\hline
\end{tabular}

Values with different letters within a column are significantly different at $\mathrm{P}<0.05$ 


\subsection{Stubble yield}

There was significant interaction between carbon and nitrogen, and nitrogen and year affecting stubble yield at $\mathrm{P}<0.05$ (Table 4 ). In addition, carbon, nitrogen and year individually had significant effect on stubble yield. Application of $\mathrm{N}_{100}$ treatments on biochar treated soils ( $\mathrm{BN}_{100}$ ) consistently increased stubble yield by $38.76 \%$ in $2014,37.16 \%$ in 2015 and $29.96 \%$ in 2016 on average compared to soils without carbon (Table 7). Similarly, BN100 significantly increased stubble yield in 2014 (by 35.36\% and 26.09\%), 2015 (by $39.76 \%$ and $22.97 \%$ ) and 2016 (by $21.49 \%$ and $12.57 \%$ ) compared to SN0 and SN50 respectively (Table 7). At a lesser magnitude, the use of $\mathrm{N}$ fertilizer at a rate of $100 \mathrm{~kg}$ ha- 1 on soils without carbon boosted stubble yield by $22.44 \%, 23.40 \%$ and $33.08 \%$ in 2014,2015 and 2016 relative to soils without N fertilizer. Application of SN100 also caused significant increases in stubble yield compared to no carbon soils, an average increase of $32.00 \%$, $28.72 \%$ and $32.01 \%$ were recorded in 2014, 2015 and 2016 respectively (Table 8). On average, biochar amended soils produced the greatest stubble yield, followed by straw treated soils and the least in no carbon soils.

\begin{tabular}{|c|c|c|c|c|c|}
\hline \multicolumn{6}{|c|}{ Treatment } \\
\hline \multirow[t]{2}{*}{ C source } & \multirow[t]{2}{*}{ Mineral N } & \multicolumn{4}{|c|}{ Stubble yield (kg ha-1) } \\
\hline & & 2014 & 2015 & 2016 & Mean \\
\hline \multirow[t]{2}{*}{ No carbon } & No & $2776 \mathrm{~d}$ & $3030 d$ & $2455 d$ & $2754 c$ \\
\hline & $\mathrm{N}_{100}$ & $3399 \mathrm{bc}$ & $3739 b$ & $3267 b c$ & $3468 b$ \\
\hline \multirow[t]{2}{*}{ Biochar } & $\mathrm{N}_{0}$ & $3295 b c$ & $3530 \mathrm{bc}$ & $3147 \mathrm{bc}$ & $3324 b$ \\
\hline & $\mathrm{N}_{100}$ & $4291 \mathrm{a}$ & $4630 a$ & $3788 \mathrm{a}$ & $4236 a$ \\
\hline \multirow[t]{2}{*}{ Straw } & No & $3170 \mathrm{bc}$ & $3312 \mathrm{~cd}$ & $3118 b c$ & $3200 b c$ \\
\hline & $\mathrm{N}_{100}$ & $4082 a$ & $4345 a$ & $3633 a$ & $4020 \mathrm{~b}$ \\
\hline
\end{tabular}

\section{Discussion}

Discussion

According to [16] soil temperature and moisture content, particularly in the $0-30 \mathrm{~cm}$ depth interval is important for crop production in dry areas. In the present study, the use of biochar and straw combined with $\mathrm{N}$-fertilizer was shown to increase soil moisture and reduce soil temperature, particularly in the topsoil (0-30 cm depth range). But biochar combined with $\mathrm{N}$-fertilizer had the greatest effect. Application of biochar has been reported to increase volumetric water content in soil, improve soil water retention and increase water infiltration [10,17]. Application of biochar could therefore be used to store more rainfall in soil and increase rainfall use efficiency in dryland areas. Increased soil water holding capacity that follows biochar addition is explained by increased total porosity in soil and specific surface area [18]. Soil moisture under biochar and straw combined with $\mathrm{N}$-fertilizer was lost slowly and the available water was maintained for a longer period of time that is available for crop plants. The increased soil moisture with biochar and straw covering can partly offset the water deficit in intensified cropping systems and this can be an ideal practice for empowering the capacity of soil water conservation in this extremely semi-arid environment. 
Studies have shown that there is a close relationship between soil temperature and soil moisture, because soil moisture can directly affect the transmission of heat on the soil surface. In turn, soil temperature can affect soil evaporation (E) and evapotranspiration (ET). Among the water conservation approaches evaluated in this study, biochar and straw combined with $\mathrm{N}$-fertilizer was most effective in reducing soil temperature, which may be related to the increased soil water content under different treatments that affected the soil thermal conductivity. Previous studies have demonstrated that each individual farming practice has its own effect on crop productivity, but integrated application of proven farming practices can enable the increase of crop yields and optimize resource use efficiency [19]. Crop residues on the soil surface typically form a barrier against evaporation, thus, maintaining the water storage in the plant root zone [20]. The findings of the present study clearly demonstrate that biochar and straw combined with $\mathrm{N}$-fertilizer can significantly decrease evaporation and evapotranspiration during the entire growing season compared to soils without carbon treatment. It suggests that the biochar and straw combined with $\mathrm{N}$ fertilization can be used to harvest more rainwater in rainfed areas or reduce the amount of irrigation in irrigation areas.

Treatment effects on soil bulk density, although small, suggested that there is potential for greater long-term impacts. The reduction effect of the treatments on soil bulk density was greater on biochar treated soils than the other treatments. The organic matter addition could cause increases in the total soil volume and decreases in the values of soil bulk density. In support, the current study showed significant increase in crop biomass when biochar was applied. [21] found that application of biochar combined with inorganic fertilizer significantly decreased bulk density. The decrease of bulk density with the addition of biochar and to a lesser extent on straw amended soils may be associated with the increase of soil aggregation and macro porosity. This study did not evaluate soil aggregate; however the data of soil bulk density allows us to draw such conclusion.

The greatest spring wheat biomass productivity was recorded on biochar treated soils and the lowest on soils without carbon treatment. Improved biomass yield in the current study could be attributed to increased nutrient availability through enhanced soil quality. Biochar amendments have previously been shown to increase crop productivity by improving soil quality [22]. Nitrogen fertilizer and biochar applied together increased wheat biomass and grain yield [23], reflecting the potential of biochar to improve the efficiency with which plants use $\mathrm{N}$-fertilizer. The higher biomass yield obtained on the straw amended soils compared to the soils without carbon in this study is attributed to the fact that in drier soils surface crop residues provided a better soil environment by reducing the temperature, conserving water, and improving soil quality resulting in better growth and hence yield [24]. The lowest yield recorded on the no carbon soils throughout this study may be related to the removal of all the aboveground biomass at the end of the cropping season. [25] showed that field practices with low carbon inputs deplete soil organic carbon and reduces crop productivity. Furthermore, the relative lower biomass found in the no carbon treated soils could be attributed to the effect of the $\mathrm{C} / \mathrm{N}$ ratio in driving down the soluble $\mathrm{N}$ pool.

The $\mathrm{C} / \mathrm{N}$ ratios within this study vary between 10.24 (no carbon) and 14.01 (biochar soils). Similar to other studies [25], the highest $\mathrm{C} / \mathrm{N}$ ratios were found in biochar treated soils, followed by straw treated soils. This increase in $\mathrm{C} / \mathrm{N}$ ratio could be explained by the increased availability of $C$ and $N$ in the soil (26) and the slower rate of decomposition [26] and thus low carbon loss. This result demonstrate that the incorporation of biochar combined with $\mathrm{N}$ fertilizer in calcerous soils could result in slower rate of decomposition as $\mathrm{C} / \mathrm{N}$ ratio influences microbial population and activity and consequently increase reduce carbon emission in semi-arid rainfed areas.

\section{Conclusions}

This study demonstrates that application of biochar improved soil conditions; decreased soil bulk density and temperature and increased soil moisture to significantly 
greater extent than the other treatments tested. Improved soil quality in biochar amended soils translated into higher biomass production in that treatment. The results of this study show the positive effects of organic matter addition to improve soil quality. The results of this study emphasize the promising potential of biochar application in rainfed spring wheat farming to improved soil quality and increased crop productivity in the semiarid Loess Plateau of China.

Supplementary Materials: The following are available online at www.mdpi.com/xxx/s1, Table S1: Table S2

Author Contributions: For research articles with several authors, a short paragraph specifying their individual contributions must be provided. The following statements should be used "Conceptualization, S. Y. and Z.R; methodology, S.Y. and Z.R; C.L; software, W.J.; validation, W.J., P.O. D and C.L.; formal analysis, S.Y.; investigation, Z.R; resources, Z.R.; data curation, S.Y.; writing-original draft preparation, S.Y.; writing - review and editing, S.Y.; P.O.D; visualization, .W.J.; supervision, Z.R.; project administration, Z.R.; funding acquisition, Z.R. All authors have read and agreed to the published version of the manuscript."

Funding: This research was financially supported by the Natural Science Foundation of Gansu province (20JR10RA543), the National Natural Science Foundation of China $(41661049,31571594)$, the Scientific Research Start-up Funds for Openly-Recruited Doctors (GAU-KYQD-2018-39).

Conflicts of Interest: "The authors declare no conflict of interest." "The funders had no role in the design of the study; in the collection, analyses, or interpretation of data; in the writing of the manuscript, or in the decision to publish the results".

\section{References}

1. He, L.; Cleverly, J.; Chen, C.; Yang, X.; Li, J.; Liu, W.; Yu, Q. Diverse responses of winter wheat yield and water use to climate change and variability on the semiarid Loess Plateau in China. 2003. Agron. J. 2014, 106, 1169-1178.

2. Sainju, U.M.,; Lenssen, A.W.; Caesar, T.; Evans, R.G. Dryland crop yields and soil organic matter as influenced by long-term tillage and cropping sequence. Agron J. 2009, 101, 243-251.

3. FAOSTAT. Statistical Yearbooks - World food and agriculture. Food Agric. Organizat. United Nations $2014,288$.

4. Yin, R..; Yin, G. China's primary programs of terrestrial ecosystem restoration: Initiation, implementation, and challenges.Environ. Manage. 2010, 45, 429-441.

5. McLain, J.E.T.; Martens, D.A. Moisture controls on trace gas fluxes in semiarid riparian soils. Soil Sci Soc Am J , 2006, 70: 367377.

6. Zhang, Z..; Qiang, H.; McHugh, A.D. Effect of conservation farming practices on soil organic matter and stratification in a mono-cropping system of Northern China. Soil Till. Res. 2016, 156(01), 173-181.

7. Laird, D.; Fleming, P.; Wang, B.; Horton, R.; Karlen, D. Biochar impact on nutrient leaching from a Midwestern agricultural soil. Geoderma, 2010, 158, 436-444.

8. Andruschkewitsch, R.; Geisseler, D.; Koch, H.J.; Ludwig, B. Effects of tillage on contents of organic carbon, nitrogen, waterstable aggregates and light fraction for four different long-term trials. Geoderma, 2013, 192: 368-377.

9. Oguntunde, P.G.; Abiodun, B.J.; Ajayi, A.E.; van de Giesen, N. Effects of charcoal production on soil physical properties in Ghana. J Plant Nutr Soil Sci 2008, 171(4), 591-596. doi:10.1002/jpln.200625185.

10. Paustian, K.; Collins, H.P.; Paul, E.A. Management controls on soil carbon. 15-49. In Cole CV (ed) Soil organic matter in temperate agroecosystems: long-term experiments in North America. CRC Press, 1997, New York.

11. Chinese Soil Taxonomy Cooperative Research Group.: [Chinese Soil Taxonomy (Revised Proposal).] Pp. 137-147. Inst. Soil Sci., Chinese Agricult. Sci. Technol.Press, Academic Sinica, Beijing, 1995. [In Chinese].

12. Carter, M.R. Soil sampling and methods of analysis, Canadian Society of Soil Science, Lewis Publisher London, 1993,823

13. Yeboah, S.; Zhang, R.; Cia, L.; Jun, W. Different carbon sources enhance system productivity and reduce greenhouse gas intensity. Plant Soil Environ. 2018, No. 64 (10), 463-469. https://doi.org/10.17221/83/2018-PSE.

14. Duncan, D.B. "Multiple range and multiple F tests". Biometrics. 1955, 11: 1-42. doi:10.2307/3001478.

15. Wu, Q.S.; Liu, H.X.; Wang, L.; Deng, C.B. Evaluation of AMSR2 soil moisture products over the contiguous United States using in situ data from the International Soil Moisture Network. Int J Appl Earth Obs Geoinf, 2016, 45:187-199. doi:10.1016/j.jag.2015.10.011.

16. Novak, J.M.; Lima I, Xing B, Gaskin JW, Steiner C, Das KC, Ahmedna M, Rehrah D, Watts DW, Busscher WJ, Schomberg H. Characterization of designer biochar produced at different temperatures and their effects on a loamy sand. Annals Env Sci, 2009, 3:195-206. 
17. Verheijen, F.; Jeffery, S.; Bastos, A.C.; Van der Velde M.; Diafas, I. Biochar Application to Soils, A Critical Scientific Review of Effects on Soil Properties, Processes and Functions. EUR 24099 EN. Office for the Official Publications of the European Communities, Luxembourg, 2010, 149.

18. Gan, Y.; Liang, C.; Chai, Q.; Lemke, R.L.; Campbell, C.A.; Zentner, R.P. Improving farming practices reduces the carbon footprint of spring wheat production. Nat Commun, 2014, 5:5012. doi:10.1038/ncomms6012

19. Lichter, K.; Govaerts, B.; Six, J.; Sayre, K.D.; Deckers, J.; Dendooven, L. Aggregation and C and N contents of soil organic matter fractions in a permanent raised-bed planting system in the highlands of central Mexico. Plant Soil, 2008, 305(1-2), 237-252. doi:10.1007/s11104-008-9557-9.

20. Ma, N.; Zhang, L.; Zhang, Y.; Yang, L.; Yu, C.; Yin, G. Timothy-Doane A, Wu Z, Zhu P, Ma X. Biochar improves soil aggregate stability and water availability in a Mollisol after three years of field application. PLOS ONE, 2016, 11(5):e0154091. doi:10.1371/journal.pone.0154091.

21. Bruun, E.W.; Muller-Stover, D.; Ambus, P.; Hauggaard-Nielsen, H. Application of biochar to soil and N2O emissions: potential effects of blending fast-pyrolysis biochar with anaerobically digested slurry. Eur. J. Soil Sci. 2011, 62: 581-589. doi: 10.1111/j.1365-2389.2011.01377x.

22. Solaiman, Z.M.; Blackwell, P.; Abbott, L.K. Direct and residual effect of biochar application on mycorrhizal root colonisation, growth and nutrition of wheat. Soil Till Rese, 2010, 48: 546-554.

23. Zou, H.; Ye, X.; Li, J, Lu J.; Fan, Q.; Yu, N. Effects of straw return in deep soils with urea addition on the soil organic carbon fractions in a semi-arid temperate cornfield. PLOS ONE, 2016, 11 (4): e0153214. doi:10.1371/journal.pone.0153214.

24. Yeboah, S.; Zhang, R.; Cai, L.; Li L., Xie, J.; Luo, Z.; Wu, J.; Antille, D.L.. Soil water content and photosynthetic capacity of spring wheat as affected by soil application of nitrogen-enriched biochar in a semiarid environment. Photosyn, 2017,55 (3): 532-542.

25. Trin

26. Clough, T.J.; Condron, L.M.; Kammann, C.; Müller, C. A review of biochar and soil nitrogen dynamics. Agrono, 2013, 3, 275293; doi: 10.3390/agronomy3020275. ISSN 2073-4395. www.mdpi.com/journal/agronomy. 